\title{
Effect of forging temperature on the structure, mechanical and functional properties of superelastic Ti-Zr-Nb bar stock for biomedical applications
}

\author{
K. E. Lukashevich ${ }^{1}$, V. A. Sheremetyev ${ }^{\dagger, 1}$, A. A. Kudryashova ${ }^{1}$, M. A. Derkach ${ }^{1}$, \\ V. A. Andreev ${ }^{2}$, S. P. Galkin ${ }^{1}$, S. D. Prokoshkin ${ }^{1}$, V. Brailovski ${ }^{3}$ \\ †'sheremetyev@misis.ru \\ ${ }^{1}$ National University of Science and Technology "MISiS", Moscow, 119049, Russia \\ ${ }^{2}$ Baikov Institute of Metallurgy and Materials Science, RAS, Moscow, 119334, Russia \\ ${ }^{3}$ Ecole de technologie superieure, Montreal, QC, H3C 1K3, Canada
}

\begin{abstract}
Ti-Zr-Nb shape memory alloys exhibit a unique combination of properties that make them suitable for bone implants: low Young's modulus, superelastic behavior, superior corrosion resistance, and non-toxicity of all the constitutive elements. In this study, superelastic Ti-19Zr-14Nb (at.\%) alloy was subjected to a combination of radial shear rolling at $900^{\circ} \mathrm{C}$ and rotary forging in a temperature range from 500 to $700^{\circ} \mathrm{C}$ to form long-length bar stocks for bone implants fabrication. Features of the grain structure, phase composition, mechanical and functional properties of the long-length bar stocks were analyzed using light microscopy, X-ray analysis, as well as during mechanical and functional tests. It was shown that after radial shear rolling at $900^{\circ} \mathrm{C}$, a heterogeneous grain structure was formed over the cross-section of the bar stock, and this structure was inherited after the subsequent rotary forging at $500^{\circ} \mathrm{C}$. With an increase in the forging temperature, the structural heterogeneity is eliminated and the grain size increases, while the hardness and strength characteristics of the material decrease. After rotary forging at $700^{\circ} \mathrm{C}$, the alloy manifests the best combination of structural, mechanical, and functional characteristics. In this state, the long-length bar stock demonstrates a homogeneous grain structure with a certain fraction of a dynamically polygonized substructure of $\beta$-phase, a satisfactory strength (UTS $\approx 580 \mathrm{MPa}$ ), a low Young's modulus $(E \approx 35 \mathrm{GPa})$, the high difference between dislocation and phase yield strength $(\Delta \sigma \approx 280 \mathrm{MPa})$, and a relatively large amount of superelastic recovery $\operatorname{strain}\left(\varepsilon_{\mathrm{r}}^{\mathrm{SE}}{ }_{\max } \approx 3.1 \%\right)$.
\end{abstract}

Keywords: Ti-Zr-Nb shape memory alloy, thermomechanical treatment, radial shear rolling, rotary forging, structure, mechanical properties, superelastic properties.

\section{Влияние температуры ковки на структуру, механические и функциональные свойства прутков из сверхупругого сплава Ti-Zr-Nb для биомедицинских применений}

\author{
Лукашевич К.Е. ${ }^{1}$, Шереметьев В. А. ${ }^{\dagger, 1}$, Кудряшова А. А. ${ }^{1}$, Деркач М. А. ${ }^{1}$, \\ Андреев В. А. ${ }^{2}$, Галкин С. П. ${ }^{1}$, Прокошкин С. Д. ${ }^{1}$, Браиловский В. ${ }^{3}$ \\ ${ }^{1}$ НИТУ МИСиС, Москва, 119049, Россия \\ ${ }^{2}$ Институт металлургии и материаловедения им. А. А. Байкова РАН, Москва, 119334, Россия \\ ${ }^{3}$ Ecole de technologie superieure, Монреаль, Н3С 1K3, Канада
}

Сплавы Ti-Zr-Nb с памятью формы демонстрируют уникальное сочетание свойств, которое делает их подходящими для костных имплантатов: низкий модуль Юнга, сверхупругие свойства, превосходная коррозионная стойкость и нетоксичность всех составляющих элементов. В данной работе сверхупругий сплав $\mathrm{Ti}-19 \mathrm{Zr}-14 \mathrm{Nb}$ (в ат.\%) был подвергнут термомеханической обработке, включающей радиально-сдвиговую прокатку при $900^{\circ} \mathrm{C}$ и ротационную ковку при $500-700^{\circ} \mathrm{C}$, с целью формирования длинномерных прутков для изготовления костных имплантатов. Методами световой микроскопии, рентгеноструктурного анализа, а также в ходе механических и функциональных испытаний были исследованы структурно-фазовое состояние материала, механические и функциональные свойства 
полученных прутков. Было показано, что в ходе радиально-сдвиговой прокатки при $900^{\circ} \mathrm{C}$ формируется неоднородная структура по поперечному сечению, которая наследуется при последующей ротационной ковке при $500^{\circ} \mathrm{C}$. С увеличением температуры ротационной ковки структурная неоднородность устраняется и увеличивается средний размер зерна, тогда как твёрдость и прочностные характеристики материала снижаются. После ротационной ковки при $700^{\circ} \mathrm{C}$ сплав демонстрирует наилучшее сочетание структурных, механических и функциональных свойств. В этом состоянии пруток имеет однородную зеренную структуру с некоторой долей динамически полигонизованной субструктуры $\beta$-фазы, достаточную прочность (UTS $\approx 580 \mathrm{MПа),} \mathrm{низкий} \mathrm{модуль} \mathrm{Юнга}(E \approx 35$ ГПа), высокую разность между дислокационным и фазовым пределами текучести $(\Delta \sigma \approx 280$ МПа) и относительно большую величину обратимой сверхупругой деформации $\left(\varepsilon_{\mathrm{r}}^{\mathrm{SE}} \max =3.1 \%\right)$.

Ключевые слов: сплав с памятью формы $\mathrm{Ti}-\mathrm{Zr}-\mathrm{Nb}$, термомеханическая обработка, радиально-сдвиговая прокатка, ротационная ковка, структура, механические свойства, сверхупругие свойства.

\section{Introduction}

The development of new technological approaches for the manufacturing of semi-finished products for orthopedic, dental, and maxillofacial implants from new highlybiocompatible metallic materials represents a significant technological challenge. Long (with the length above $1500 \mathrm{~mm}$ ) high quality 3-8 mm diameter bars suitable for the manufacture of milling products on modern production lines are the most in-demand $[1,2]$. In the last decade, nickelfree $\mathrm{Ti}-\mathrm{Nb}(\mathrm{Zr})$-based shape memory alloys (SMA) have become prospective material candidates for load-bearing implants, due to their unique combination of mechanical (low-stiffness and plateau-like superelastic behavior) and biological (excellent corrosion resistance and non-toxicity of all the constitutive elements) properties [3-5].

The structure, phase composition, texture, and consequently, the mechanical and functional properties of SMAs are commonly controlled by thermomechanical treatments (TMT) [6]. Combining the radial shear rolling (RSR) and rotary forging (RF) processes allows the formation of a favorable phase composition, structure and texture in semi-finished SMA products [7,8]. Applying radial shear rolling allows the efficient transformation of an ingot into a 10-12 $\mathrm{mm}$ diameter bar with a refined and compacted structure along the bar cross-section [9]. A subsequent rotary forging allows the manufacture of a long-length 3-8 $\mathrm{mm}$ diameter bar stock with a homogenized structure [7]. Since rotary forging conditions determine the final structure of the bar stock, a rational selection of the RF temperature and deformation conditions is critical for the obtainment of an adequate set of properties of the final product. It was shown that combining $900^{\circ} \mathrm{C}$ RSR with $800^{\circ} \mathrm{C}$ RF leads to a homogeneous, predominantly dynamically polygonized dislocation $\beta$-phase substructure. During functional cyclic tests, this structure manifests a favorable combination of extended fatigue life and a relatively low value of residual (unrecoverable) strains [7]. However, the next study [8] showed that multi-stage $\mathrm{RF}$ at $800^{\circ} \mathrm{C}$ with incrementally increasing strains to obtain bars of smaller diameter led to the surface quality deterioration caused by significant oxidation at this temperature.

In this work, the $900^{\circ} \mathrm{C}$ RSR is combined with a lower-temperature $\left(500-700^{\circ} \mathrm{C}\right) \mathrm{RF}$, and the effect of this combination on the structure, phase state, texture, mechanical and functional properties of Ti-Zr-Nb long-length bar stocks was studied.

\section{Materials and methods}

A $30 \mathrm{~kg}$-weight, $160 \mathrm{~mm}$-diameter ingot with a nominal atomic composition (at.\%) of $\mathrm{Ti}-19 \mathrm{Zr}-14 \mathrm{Nb}$ was prepared by vacuum arc melting. The ingot was re-melted at least 3 times to ensure compositional homogeneity. The melting of the alloy resulted in a low amount of impurities $(\mathrm{O}<0.05$, $\mathrm{C}<0.01, \mathrm{~N}<0.01, \mathrm{H}<0.01$, wt.\%). Samples with a diameter of $55 \mathrm{~mm}$ were cut by electrical discharge machining from the as-received ingot and deformed by RSR $\left(900^{\circ} \mathrm{C}, e=2.4\right.$, $d=17 \mathrm{~mm}$ ). Further, the obtained $1500-1700 \mathrm{~mm}$-long bars were subjected to $\mathrm{RF}$ in the $500-700^{\circ} \mathrm{C}$ temperature range $(e=2, d=6.2 \mathrm{~mm})$ and air-cooled after the operation. At the last stage of processing, the bars were straightened and grinded to a $5.5 \mathrm{~mm}$ diameter.

For the structure and phase investigations, $3 \mathrm{~mm}$-high disk samples were cut from the bar stock. The cross-sectional surfaces of the samples were subjected to multi-stage grinding and polishing on an ATM "Saphir 560" machine. First, the samples were ground for 2 minutes under $10 \mathrm{~N}$ of load on emery paper with a grain size ranging from 320 to 4000 . Then, polishing was carried out for 40 minutes under $30 \mathrm{~N}$ of load using silicon oxide suspension Eposil F with a particle size of $0.1 \mu \mathrm{m}$, applied to ATM Iota cloth, with an addition of ammonia solution, hydrogen peroxide, and liquid soap. Finally, etching was carried out for $60 \mathrm{~s}$ using $1 \mathrm{HF}: 3 \mathrm{HNO}_{3}: 6 \mathrm{H}_{2} \mathrm{O}$ solution to remove the defective layer and allow the identification of grain boundaries. The grain structure of the prepared thin sections was analyzed using a "Versamet-2 Union" optical microscope equipped with a "Nikon D90" camera and applying the random linear intercept method [10]. Phase analysis was conducted using a PANalytical X'pert Pro X-Ray diffractometer $\left(\mathrm{Cu}-\mathrm{K}_{\alpha}\right.$ radiation in the 30 to $80^{\circ}$ range of Bragg angles $2 \theta$, with an exposure of $4 \mathrm{~s}$, and a step size of $0.1^{\circ} 2 \theta$ ).

To characterize the mechanical properties at room temperature, three types of tests were carried out. First, Vickers hardness was measured using a "Metkon" microhardness tester; 10 measurements were made for each specimen under a load of $1 \mathrm{~kg}$ and with a dwell time of $10 \mathrm{~s}$. Next, static tensile testing to failure was carried out at a strain rate of $0.02 \mathrm{~s}^{-1}$ using an "MTS MiniBionix 858" testing machine and as-forged $4 \mathrm{~mm}$-diameter - $50 \mathrm{~mm}$-gauge length samples (three samples per each RF temperature). From the "stressstrain" curves, the apparent Young's modulus E, the relative elongation to failure $\delta$, the transformation yield stress $\sigma_{\text {tr }}$ the dislocation yield stress $\sigma_{\text {dis }}$, the difference between the dislocation and transformation yield stresses $\Delta \sigma=\sigma_{\text {dis }}-\sigma_{\text {tr' }}$, 
and the ultimate tensile strength UTS were determined; their values were averaged, and deviations calculated. Finally, using the same type of samples, loading-unloading cyclic testing was carried out up to $15 \%$ of the accumulated strain with a $0.5 \%$ strain increase by increments in each subsequent cycle.

\section{Results and discussion}

The microstructures formed in Ti-19Zr-14Nb alloy after different RSR $+\mathrm{RF}$ processing conditions are shown in Fig. 1. After RSR, a significantly heterogeneous structure is formed over the cross-section of the bar stock. The grain size gradually increases from the edge $(5 \mu \mathrm{m})$ to the center $(32 \mu \mathrm{m})$ of the workpiece. After $\mathrm{RF}$ at $500^{\circ} \mathrm{C}$, the heterogeneity remains while the average grain size decreases in all three zones. It should be noted that during RF, the average grain size decreases more rapidly in the peripheral zone (from 5 to $2 \mu \mathrm{m}$ ) than in the central ( 32 to $26 \mu \mathrm{m}$ ) and intermediate ( 14 to $11 \mu \mathrm{m}$ ) ones, which indicates a significant development of the primary static recrystallization process during intermediate heatings at this temperature. RF at $600^{\circ} \mathrm{C}$ and $700^{\circ} \mathrm{C}$ lead to homogenization of the grain structures over the bar cross-sections and the formation of equiaxed grain structures with an average grain size of $\approx 7 \mu \mathrm{m}\left(600^{\circ} \mathrm{C}\right)$ and $\approx 12 \mu \mathrm{m}\left(700^{\circ} \mathrm{C}\right)$. It should be noted that the grain microstructure is quite uniform along the length of the bar stocks, since during RF a small temperature gradient is achieved, which does not exceed $25^{\circ} \mathrm{C}$.
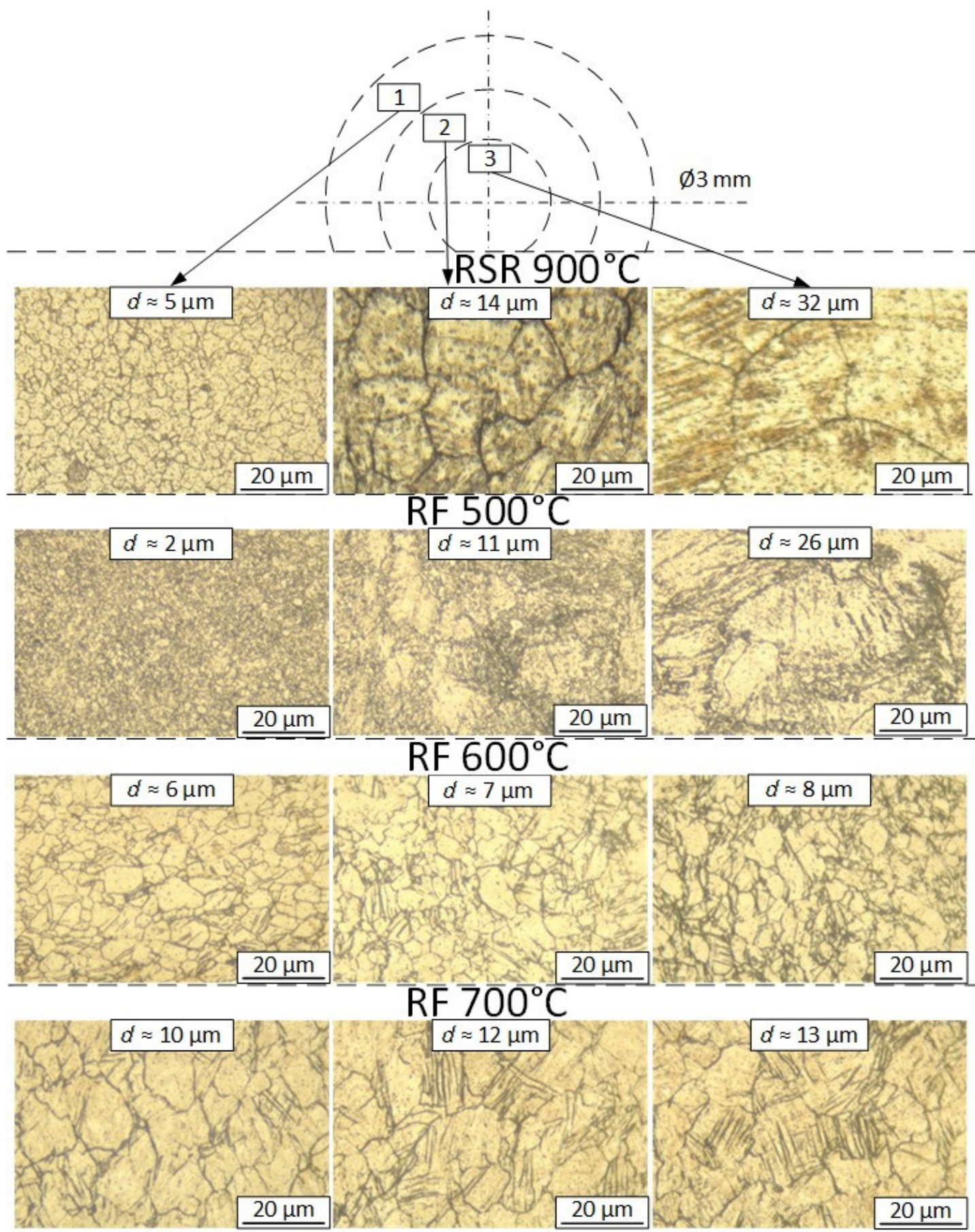

Fig. 1. (Color online) Ti-Zr-Nb alloy micrographs after RSR and $\mathrm{RF} 500^{\circ} \mathrm{C}, \mathrm{RF} 600^{\circ} \mathrm{C}, \mathrm{RF} 700^{\circ} \mathrm{C}$. 
The X-ray diffractograms of the RSR + RF-processed structures are presented in Fig. $2 \mathrm{a}$. In all the cases, the bcc $\beta$-phase is the main one. After RF at 500 and $600^{\circ} \mathrm{C}$, a small amount of orthorhombic $\alpha^{\prime \prime}$-martensite is present. The changes in the $\beta$-phase lattice defectness level caused by different processing conditions are correlated with the changes in the half-width of selected $\beta$-phase X-ray lines (Fig. $2 \mathrm{~b}$ ). As the RF temperature increases, the widths of all $\beta$-phase lines decrease, thus indicating lower substructural material hardening at higher deformation temperatures.

The stress-strain curves obtained during static tensile testing are shown in Fig. 3 a, and the mechanical properties are summarized in Table 1. The alloy demonstrates the most hardened state after $\mathrm{RF}$ at $500^{\circ} \mathrm{C}(\mathrm{UTS}=720 \pm 18 \mathrm{MPa})$. With an increase in the RF temperature, the maximum strength decreases to reach $580 \pm 22 \mathrm{MPa}$ after RF at $700^{\circ} \mathrm{C}$. After RF at any temperature, the alloy has an apparent Young's modulus of approximately $40 \mathrm{GPa}$ and an elongation to failure of about $11 \%$. The measured hardness correlates well with the UTS values: the highest hardness corresponds to $\mathrm{RF}$ at $500^{\circ} \mathrm{C}-$ $\mathrm{HV} 216 \mathrm{MPa}$, while the lowest hardness corresponds to $\mathrm{RF}$ at $700^{\circ} \mathrm{C}-\mathrm{HV} 190 \mathrm{MPa}$.

Typical loading-unloading stress-strain diagrams obtained during cyclic testing of the $\mathrm{Ti}-\mathrm{Zr}$-Nb samples are shown in Fig. $3 \mathrm{~b}-\mathrm{d}$. To characterize the shape recovery properties quantitatively, the following parameters were measured
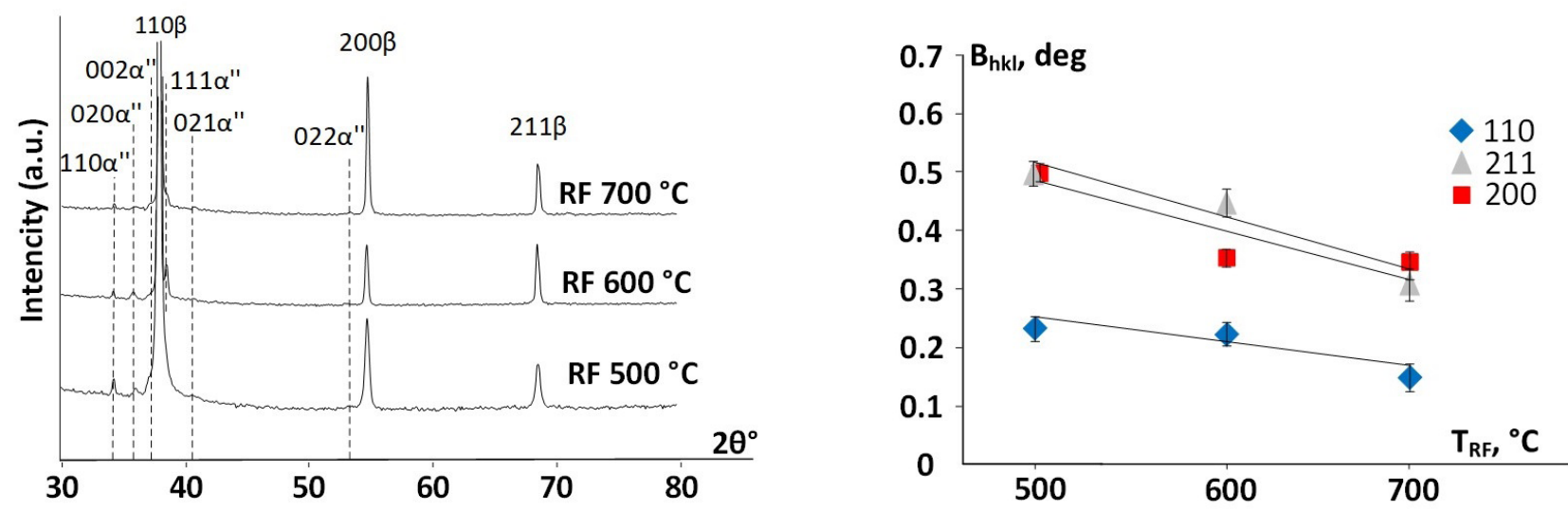

a

$\mathrm{b}$

Fig. 2. (Color online) Results of the X-ray diffraction analysis of the Ti-Zr-Nb alloy as a function of the RF temperature: $\mathrm{X}$-ray diffractograms (a), half-width of the selected $\beta$-phase X-ray lines (b).
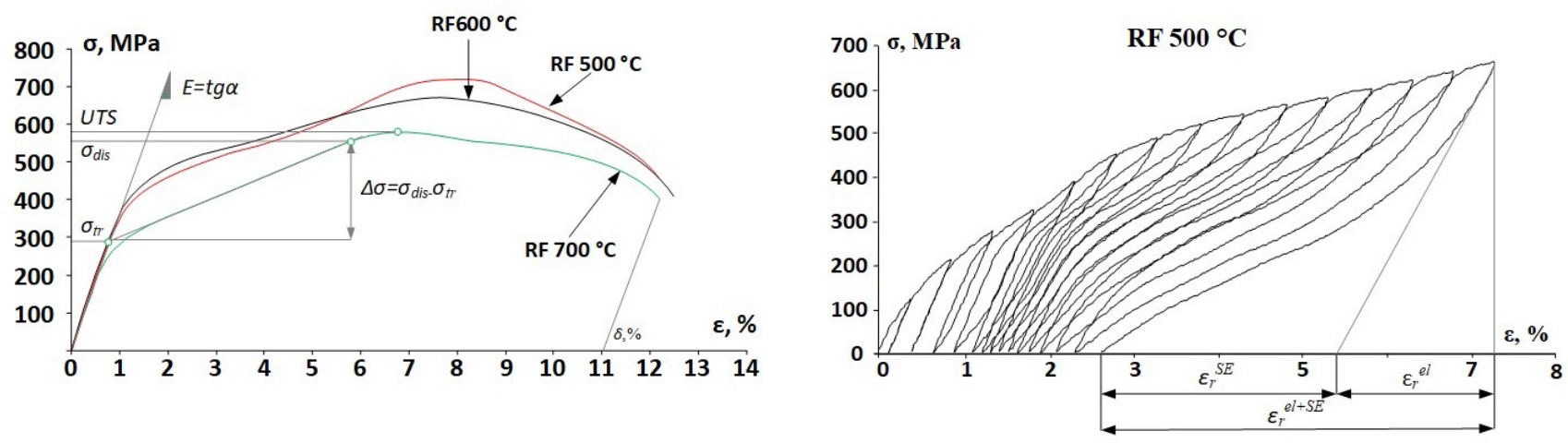

a

$\mathrm{b}$
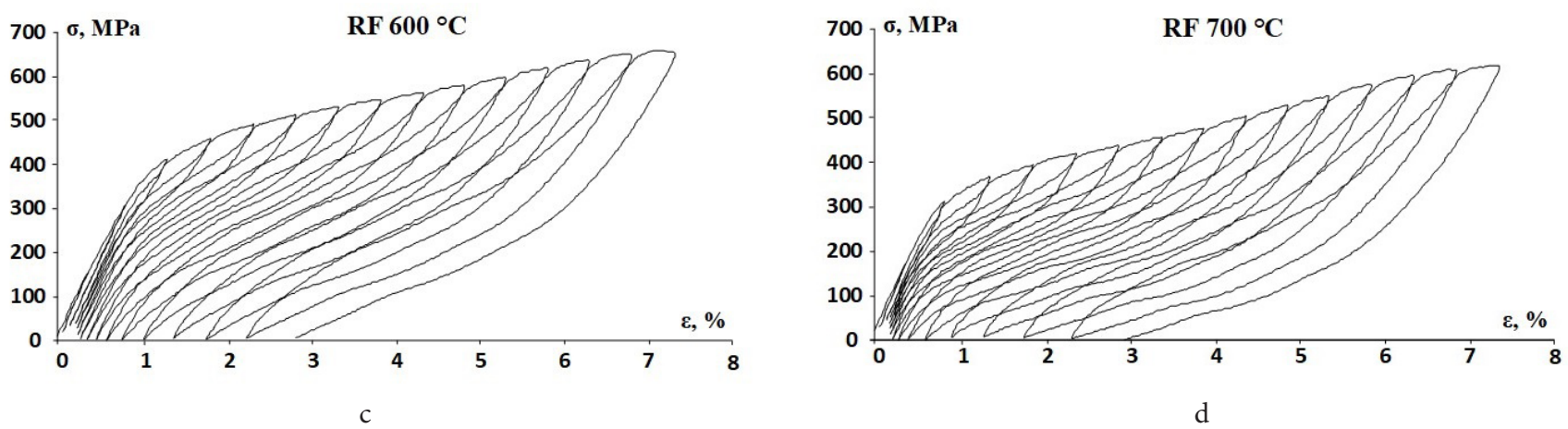

Fig. 3. (Color online) Result of the static tensile testing to failure (a); cyclic stress-strain diagrams after RSR $+\mathrm{RF}$ at $500^{\circ} \mathrm{C}(\mathrm{b}), 600^{\circ} \mathrm{C}(\mathrm{c})$, $700^{\circ} \mathrm{C}(\mathrm{d})$. The characteristic stress and strain metrics are respectively illustrated in $\mathrm{RF}$ at $700^{\circ} \mathrm{C}$ (stresses) (a) and $\mathrm{RF}$ at $500^{\circ} \mathrm{C}$ (strains) (b). 
Table 1. Mechanical properties of the Ti-Zr-Nb alloy after RSR+RF.

\begin{tabular}{|c|c|c|c|c|c|c|c|}
\hline TMT route $\mathrm{RSR}+\mathrm{RF}$ at: & $E, \mathrm{GPa}$ & $\sigma_{\text {tr }}, \mathrm{MPa}$ & $\sigma_{\text {dis }}, \mathrm{MPa}$ & $\Delta \sigma, \mathrm{MPa}$ & $\mathrm{UTS}, \mathrm{MPa}$ & $\delta, \%$ & $\mathrm{HV}, \mathrm{MPa}$ \\
\hline $500^{\circ} \mathrm{C}$ & $41 \pm 5$ & $415 \pm 28$ & $700 \pm 26$ & $285 \pm 27$ & $720 \pm 18$ & $10.9 \pm 1.4$ & $216 \pm 8$ \\
\hline $600^{\circ} \mathrm{C}$ & $43 \pm 4$ & $460 \pm 33$ & $645 \pm 29$ & $185 \pm 31$ & $670 \pm 21$ & $11.3 \pm 1.1$ & $210 \pm 7$ \\
\hline $700^{\circ} \mathrm{C}$ & $35 \pm 4$ & $290 \pm 23$ & $570 \pm 25$ & $280 \pm 24$ & $580 \pm 17$ & $11.0 \pm 1.2$ & $190 \pm 3$ \\
\hline
\end{tabular}

from the stress-strain diagrams (Fig. $3 b$ ): $\varepsilon_{\mathrm{el}}$ - the elastic strain recovered upon unloading, $\varepsilon_{\mathrm{r}}^{\mathrm{SE}}-$ the superelastic strain recovered due to reverse martensitic transformation, and $\varepsilon_{\mathrm{r}}^{\mathrm{el}+\mathrm{SE}}-$ the total (elastic + superelastic) recovery strain. Table 2 shows the functional characteristics of the material in a cycle with maximum recovery strain due to superelasticity.

The alloy after $\mathrm{RF}$ at $500^{\circ} \mathrm{C}$ demonstrates a particular behavior during testing, which is characterized by high residual strains in the first cycles. Beginning from the $5^{\text {th }}$ cycle, the sample exhibits superelasticity. This phenomenon can be explained by a significant heterogeneity of the microstructure. Samples after $\mathrm{RF}$ at $500^{\circ} \mathrm{C}$ demonstrate the lowest superelastic strains $\left(\varepsilon_{\mathrm{r}}^{\mathrm{SE}}=2.8 \%\right)$, but the highest elastic strains $\left(\varepsilon_{\mathrm{r} \text { max }}^{\mathrm{el}}=1.9 \%\right)$, which result in the highest values of the total recovery strain $\left(\varepsilon_{\mathrm{r}}^{\mathrm{el}+\mathrm{SE}} \mathrm{max}_{\max }=4.7 \%\right)$. The maximum value of the superelastic recovery strain $\left(\varepsilon_{\mathrm{r}}^{\mathrm{SE}}{ }_{\max }=3.1 \%\right)$ is demonstrated after $\mathrm{RF}$ at $700^{\circ} \mathrm{C}$ and this is explained by the formation in the alloy of a certain fraction of a dynamically polygonized substructure of $\beta$-phase. The formation of a more favorable crystallographic texture after $\mathrm{RF}$ at $700^{\circ} \mathrm{C}$ can also explain such an improvement in the superelastic behavior, but this aspect needs future investigation.

Table 2. Elastic and superelastic recoveries of the Ti-Zr-Nb alloy after $\mathrm{RSR}+\mathrm{RT}$.

\begin{tabular}{|c|c|c|c|c|}
\hline $\begin{array}{c}\text { TMT route: } \\
\text { RSR+RF at: }\end{array}$ & $\begin{array}{c}\text { Cycle } \\
\text { number }\end{array}$ & $\varepsilon_{\mathrm{r}}^{\varepsilon_{\text {max }}^{\mathrm{el}+\mathrm{SE}}} \%$ & $\varepsilon_{\mathrm{r} \text { max }}^{\mathrm{el}} \%$ & $\varepsilon_{\mathrm{r} \text { max }}^{\mathrm{SE}} \%$ \\
\hline $500^{\circ} \mathrm{C}$ & 15 & 4.7 & 1.9 & 2.8 \\
\hline $600^{\circ} \mathrm{C}$ & 14 & 4.5 & 1.7 & 2.8 \\
\hline $700^{\circ} \mathrm{C}$ & 13 & 4.5 & 1.4 & 3.1 \\
\hline
\end{tabular}

\section{Conclusions}

After RSR at $900^{\circ} \mathrm{C}$, a heterogeneous grain structure over the cross-section of the bar stock was formed, and this structure was inherited after the subsequent $\mathrm{RF}$ at $500^{\circ} \mathrm{C}$. With an increase in the RF temperature to $600-700^{\circ} \mathrm{C}$ and the development of the recrystallization process, the grain structure is refined and homogenized. After RF at $700^{\circ} \mathrm{C}$, the alloy manifests the best combination of the structural, mechanical, and functional properties. In this state, longlength bar stocks demonstrate a homogeneous grain structure, a satisfactory strength (UTS $\approx 580 \mathrm{MPa}$ ), a low Young's modulus $(E \approx 35 \mathrm{GPa})$, and a relatively large value of superelastic recovery strain $\left(\varepsilon_{\mathrm{r}}^{\mathrm{SE}}{ }_{\text {max }} \approx 3.1 \%\right)$.

Acknowledgments. The work was funded by the Russian Science Foundation (project № 22-29-01562).

\section{References}

1. S.A. Muslov, V.A. Andreev, A.B. Bondarev, P.Y. Sukhochev. In: Superelastic alloys with shape memory effect in science, technology and medicine. Moscow, Publishing House "Folium" (2012) 455 p.

2. V.A. Sheremet'ev, A.A. Kudryashova, Suan Ta Dinh, S. P. Galkin, S. D. Prokoshkin, V. Brailovski. Metallurg. 63, 51 (2019). Crossref

3. M. Geetha, A. K. Singh, R. Asocamani, A. K. Gogia. Progr. Mater. Sci. 54, 397 (2009). Crossref

4. H.Y. Kim, J. Fu, H. Tobe, J.I. Kim, S. Miyazaki. Shape Mem. Superelasticity. 1, 107 (2015). Crossref

5. M. J. Niinomi. Mech Behav Biomed Mater. 1, 30 (2008). Crossref

6. A.R. Vieira Nunes, S. Borborema, L.S. Araújo, L. Malet, J. Dille, L. Henrique de Almeida. J. Alloys Compd. 820, 153078 (2020). Crossref

7. V. Sheremetyev, A. Kudryashova, V. Cheverikin, A. Korotitskiy, S. Galkin, S. Prokoshkin, V. Brailovski. J. Alloys Compd. 800, 320 (2019). Crossref

8. A. Kudryashova, V. Sheremetyev, K. Lukashevich, V. Cheverikin, K. Inaekyan, S. Galkin, S. Prokoshkin, V. Brailovski. J. Alloys Compd. 843, 156066 (2020). Crossref

9. S.P. Galkin, B.A. Romantsev, E. A. Kharitonov. CIS Iron Steel Rev. 9, 35 (2014).

10. V.A. Zaimovsky, E.I. Polyak, S.A. Faldin. In: The Structure and Properties of Metals and Alloys (ed. by M.L. Bernstein). Moscow, Publishing Office of the Moscow Institute of Steel and Alloys (1998) 91 p. 